\title{
Late Palaeozoic foliage from China displays affinities to Cycadales rather than to Bennettitales necessitating a re-evaluation of the Palaeozoic Pterophyllum species
}

Christian Pott, Stephen Mcloughlin, and Anna Lindström

Acta Palaeontologica Polonica 55 (1), 2010: 157-168 doi: http://dx.doi.org/10.4202/app.2009.0070

The epidermal anatomy of Pseudoctenis samchokense is described revealing non-bennettitalean characters of these leaves from the Permo-Carboniferous of China (and Korea). The specimens were originally described as Pterophyllum samchokense suggesting a bennettitalean affinity. They can no longer be considered bennettitalean since their cuticles lack the distinctive brachyparacytic stomata of that clade. Pterophyllum was originally erected as a morphogenus for segmented leaves from the Mesozoic and has subsequently been clearly assigned to the Bennettitales. The segmented leaves from the Permo-Carboniferous of Shanxi and Hebei, China described herein require a new ordinal and generic assignment since the non-bennettitalean cuticular characters documented reinforce the uncertainties in attribution of any foliage older than Late Triassic to the Bennettitales. Based on leaf-architecture and epidermal anatomical characters, the specimens are at best assigned to the cycadalean genus Pseudoctenis. This genus was formerly known only from Mesozoic rocks. Consequently, the specimens are highly significant, as they are among the oldest known vegetative remains of cycads. Re-evaluation of the affinities of all specimens assigned to Pterophyllum from Palaeozoic rocks is thus essential. Based on a review of other Permian-Carboniferous fossil leaves assigned to Pterophyllum, we conclude that none yet reveals definitive bennettitalean characters.

Key words: Cycadales, Bennettitales, Pseudoctenis, Pterophyllum, cuticle analysis, epidermal anatomy, Carboniferous, Permian, China.

Christian Pott [christian.pott@nrm.se], Stephen McLoughlin [ $\underline{\text { steve.mcloughlin@nrm.se }}$ ], and Anna Lindström [anna.lindstrom@nrm.se], Naturhistoriska riksmuseet, Sektionen för paleobotanik, Box 50007, SE-104 05 Stockholm, Sweden. 
This is an open-access article distributed under the terms of the Creative Commons

Attribution License (for details please see creativecommons.org), which permits unrestricted use, distribution, and reproduction in any medium, provided the original author and source are credited.

For Full text $(1,067.8 \mathrm{kB})$ 